\title{
Use of mixedwood stands by wintering white-tailed deer in southern New Brunswick
}

\author{
by Dwayne L. Sabine ${ }^{1,2}$, Warren B. Ballard ${ }^{3}$, Graham Forbes ${ }^{1,4}$, Jeff Bowman ${ }^{5}$ \\ and Heather Whitlaw ${ }^{1,6}$
}

On the northern edge of their range, white-tailed deer (Odocoileus virginianus) congregate during winter to cope with severe climate conditions. We documented the winter habitat use of deer in southern New Brunswick, where winters are of moderate severity, and tested predictions concerning the influence of food and cover availability on habitat use by deer under different snow depth regimes. Sixty-three radio-collared deer were monitored during the winters of 1995 to 1997 . Within wintering areas, deer showed a preference for mixedwoods. Mixedwood stands provided only moderate amounts of food and cover relative to some other cover types, but were the only type to provide both simultaneously. Current habitat management guidelines in parts of northeastern North America consider critical habitat for wintering deer to be softwood-dominated stands. These guidelines may not provide adequate habitat in this region, since deer appear to use mixedwood stands under some conditions.

Key words: deer, deer wintering area, deer yard, habitat, habitat management, mixedwood, Odocoileus, winter, yard

À la limite nordique de son aire de distribution, le cerf de Virginie (Odocoileus virgianus) se rassemble au cours de l'hiver pour faire face aux difficiles conditions climatiques. Nous avons documenté l'utilisation de l'habitat hivernal du chevreuil dans le sud du NouveauBrunswick, où les hivers sont modérés, et nous avons fait l'essai de prédictions se rapportant à l'influence de la disponibilité de la nourriture et du couvert dans l'habitat utilisé par le chevreuil selon différents régimes d'épaisseur de neige. Soixante-trois chevreuils munis de radio-émetteur fixé au cou ont été surveillés au cours des hivers de 1995 à 1997. Dans les ravages, le chevreuil a démontré une préférence pour les peuplements mélangés. Les peuplements mélangés ont procuré seulement des quantités modérées de nourriture et de couvert relativement à d'autres types de couvert, mais ils étaient le seul type à fournir les deux à la fois. Les recommandations actuelles d'aménagement des ravages dans certaines régions de l'Amérique du Nord considère comme habitat critique pour la saison d'hiver du chevreuil comme étant les peuplements dominés par les résineux. Ces recommandations ne constituent probablement pas un ravage adéquat dans cette région, puisque le chevreuil semble utiliser les peuplements mélangés dans certaines circonstances.

Mots-clés : cerf, zone d'hivernage, ravage de chevreuil, aménagement de l'habitat, peuplements mélangés, Odocoileus, hiver, ravage

\section{Introduction}

White-tailed deer (Odocoileus virginianus) usually congregate Jduring winter in distinct traditional areas or "yards" throughout the north of their range (Verme 1973, Huot 1974, Drolet 1976). Where winters are severe and snow accumulations considerable, yarding behaviour includes a shift in habitat use, typically to sites providing cover from climate conditions. Deer yards show consistent characteristics throughout northern North America. Where snow cover normally exceeds $30 \mathrm{~cm}$, wintering areas are typically at low elevations, on south-facing slopes, and in mature, dense, coniferous forest (Telfer 1970, Euler and Thurston 1980, Pauley et al. 1993). In areas of less snow, mature coniferous cover is less essential (Kucera 1976, Beier and McCullough 1990).

Yarding is generally considered to be an energy-conserving behaviour because the canopy cover in coniferous stands reduces snow depths compared to other stand types (Moen 1976).

\footnotetext{
${ }^{1}$ New Brunswick Cooperative Fish and Wildlife Research Unit, University of New Brunswick, Box 44555, Fredericton, N.B. E3B 6C2

${ }^{2}$ E-mail: dwaynesabine@hotmail.com

${ }^{3}$ Author for correspondence. Department of Range, Wildlife, and Fisheries Management, Texas Tech University, Lubbock, TX, USA, 79409-2125. E-mail: wballard@ttacs.ttu.edu

${ }^{4}$ E-mail: forbes@unb.ca

${ }^{5}$ Current address: Department of Biology, Carleton University, Ottawa, Ont. K1S 5B6. E-mail: jbowman@canada.com

${ }^{6}$ Current address: New Mexico Department of Game and Fish, Santa Fe, NM, USA, 87504, E-mail: hwhitlaw@state.nm.us
}

Communal trails in yards reduce locomotive costs for deer. Wind speed and temperature ranges tend to be lower, while mean temperature, relative humidity, and infrared radiation flux tend to be greater in conifer stands relative to other forest types. These characteristics result in lower convective heat loss, thereby reducing thermoregulation costs for deer (Moen 1968, Ozoga 1968, Ozoga and Gysel 1972). It has been suggested that yarding is also a predation-avoidance strategy (Nelson and Mech 1981, Messier and Barrette 1985), although evidence supporting this hypothesis is equivocal (Whitlaw et al. 1998). Reduced snow accumulation, the presence of trails, and improved predator detection at high deer densities may reduce predation rates. Consequently, deer distribution in regions with severe winters is more dependent on available shelter than on forage (Hamerstrom and Blake 1939, Pauley et al. 1993), because browse availability in coniferous stands is usually low (Webb 1948, Ozoga and Gysel 1972, Monthey 1984).

Snow depth begins to restrict white-tailed deer movements at $25-30 \mathrm{~cm}$ (knee height) (Telfer 1970) and movements become severely restricted when snow depths reach $40 \mathrm{~cm}$ (Kelsall 1969, Kelsall and Prescott 1971). Deer are confined to shelter stands as depths reach $50 \mathrm{~cm}$ (Telfer 1970). Therefore, use of stands that reduce snow depth is likely obligatory for white-tailed deer when snow accumulations exceed $40 \mathrm{~cm}$ in the open. At depths $<25 \mathrm{~cm}$, the benefit of reduced locomotive costs is probably unimportant, as the energetic cost of locomotion is only slightly greater than that in no snow (Moen 1976, Parker et al. 1984). However, shifts in habitat use occur if depths 
exceed $20 \mathrm{~cm}$ (Kelsall and Prescott 1971). At snow depths $<25 \mathrm{~cm}$, the effect of snow on food availability is likely more important than on locomotive cost, as snow forces a dietary shift from grasses and forbs to browse; because this shift reduces energy intake, decreases feeding time, and increases rumination time, the thermal benefit of shelter stands becomes more important compared to snow-free periods at similar temperatures (Beier and McCullough 1990). Thus, conditions influencing habitat use by deer during winter appear to be complex, and include snow accumulation, decreasing temperatures, and food availability. No one factor is singly responsible, and the relative importance of each factor may change in response to climatic conditions.

In parts of eastern Canada, including southern New Brunswick, winter climate conditions are moderate and variable. In an attempt to provide suitable winter habitat for deer, the New Brunswick Department of Natural Resources and Energy maintains approximately 900 mature conifer-dominated sites (268 000 ha) on Crown land as deer wintering areas. We examined habitat use by white-tailed deer in deer wintering areas under moderate winter climate conditions. We hypothesized that winter habitat selection under severe climate conditions is a function of cover availability irrespective of food availability. Conversely, under mild conditions, winter habitat selection is a function of food availability. Our predictions were that: 1) at snow depths $>40 \mathrm{~cm}$, cover availability primarily determines deer habitat selection; thus, softwood stands are preferred; 2) at snow depths $20-40 \mathrm{~cm}$, both food and cover availability influence habitat selection; thus, use of softwood stands diminishes in favour of open-canopy stands with high browse production; and 3) at snow depths $<20 \mathrm{~cm}$, food availability primarily determines habitat selection; thus, softwood stands are avoided and open-canopy stands or other open habitats are preferred.

\section{Methods}

The study was conducted during December 1993 - April 1997 in a $757 \mathrm{~km}^{2}$ area, spanning approximately $38 \mathrm{~km}$ $(\mathrm{N}-\mathrm{S})$ by $49 \mathrm{~km}(\mathrm{E}-\mathrm{W})$, between the Canaan River and the town of Sussex in southern New Brunswick $\left(45^{\circ} 55^{\prime} \mathrm{N}\right.$, $65^{\circ} 40^{\prime} \mathrm{W}$ ). The northern section of the study area consisted mainly of Crown lands and large industrial holdings subjected to intensive forest management, which resulted in a pattern of large (20-100 ha) openings and many young plantations and naturally regenerated stands. Topography was flat, and forest cover was primarily mixedwood stands of red spruce (Picea rubens), white spruce $(P$. glauca), and shade-intolerant hardwoods: trembling aspen (Populus tremuloides), largetooth aspen $(P$. grandidentata), red maple (Acer rubrum), and white birch (Betula papyrifera). Young plantations of black spruce ( $P$. mariana) and jack pine (Pinus banksiana) were common, and black spruce also occurred on many poorly drained sites. The southern section consisted mainly of small private woodlots and farms. Harvest patterns on these woodlots resulted in small, irregular clearcuts ( $<20 \mathrm{ha})$ and partial cuts. Topography ranged from flat to ridged, and forest cover was similar to the north site. The primary difference compared to the northern section was the prevalence of agricultural land. In addition, several tree species were present, although uncommon, on the southern section and absent in the north: eastern white cedar (Thuja occidentalis) and eastern hemlock
(Tsuga canadensis) on the lowlands and mixed stands of rec spruce and shade-tolerant hardwoods (sugar maple (Aces saccharum), yellow birch (Betula alleghaniensis), and American beech (Fagus grandifolia)) at higher elevations.

The climate of southern New Brunswick is strongly influ. enced by the close proximity of the Bay of Fundy, resulting in a distinct maritime influence that moderates summer anc winter climatic extremes (Phillips 1990). Yarding period defined as the average yearly number of days with open-are snow depths $>50 \mathrm{~cm}$, is only 50 days within the study area com. pared to 110 days in parts of northern New Brunswick (Anor 1991). Weekly severity indices collected in southern New Brunswick from 1980-1995 indicated that, in addition tc being moderate, winter conditions also varied considerably within and among years (Sabine 1999). Total snow depth was measured in recent clearcuts with ten stakes systematically distributed $10 \mathrm{~m}$ apart along a straight line. Snow depth was measured weekly, as well as before and after any thaw or snowfall. Sinking depths were not measured because they do not correlate closely to deer behaviour (Pauley et al. 1993), and are imprecise, varying considerably both within and among days (Potvin and Huot 1983).

Deer were captured and radiocollared according to methods described by Ballard et al. (1998). Deer locations were estimated by triangulation based on at least three azimuths (White and Garrott 1990). Azimuths were measured from known locations with a hand-held, three-element yagi antenna. Location estimates were generated in New Brunswick Stereographic Grid format using the software package LOCATE (Pacer, Truro, Nova Scotia, Canada). Telemetry error ellipses $(95 \%)$ were derived using the maximum likelihood estimator (Nams 1990). Locations were determined several times per week. Fixedwing aircraft were used to relocate deer whose signals could not be obtained from the ground.

Deer may shift winter habitat use between day and night (Beier and McCullough 1990). To determine if daily habitat use differed, a paired sample of 460 day and night locations was collected for 13 deer during winter 1995-96. Numbers of deer locations per cover type were square-root transformed, and differences between intervals were assessed with a two-factor ANOVA that considered both cover type and interval as factors. White-tailed deer habitat selection may differ between sexes (Beier and McCullough 1990). Differences in cover type use between male and female deer were similarly assessed with a two-factor ANOVA, considering cover type and sex as factors.

The software package CALHOME was used to generate $95 \%$ minimum convex polygon home range estimates for individual deer. Aggregations of deer using distinct wintering areas were defined as sub-populations. Wintering areas were delineated by polygons encompassing all outermost winter locations for these sub-populations. The resulting point locations, home ranges, and wintering areas, were incorporated into the New Brunswick Department of Natural Resources and Energy (NBDNRE) ARC/INFO Geographical Information System (GIS) database to obtain forest stand descriptions.

Forest stands were reclassified from a digital forest inventory (which was based on 1993 aerial photography) into categories that reflected broad overstory cover types. Seven categories were used to minimize data fragmentation: (1) softwood stands ( $>75 \%$ softwood, older than sapling); (2) hard- 
wood stands ( $>75 \%$ hardwood, older than sapling); (3) plantations (softwood plantations, less than 20 years old); (4) regenerating stands (naturally regenerating from harvest intervention; trees $<3 \mathrm{~m}$ in height); (5) mixedwood saplings ( $<75 \%$ softwood or hardwood dominated, sapling stage); (6) mixedwood ( $<75 \%$ softwood or hardwood dominated, older than sapling); and (7) agricultural land. Pure stands of shadetolerant hardwoods were absent within the wintering areas studied, thus, the hardwood category is composed entirely of stands of shade-intolerant species. Mixedwood stands where the hardwood component was dominated by shade-tolerant rather than shade-intolerant species were absent on two of three wintering areas studied, and comprised only $5 \%$ of all mixedwood stands on the remaining wintering area; thus, these classes of mixedwood stands were not separated.

Habitat use was examined at two spatial scales, since habitat selection can involve a hierarchy of spatial and temporal scales (Orians and Wittenberger 1991, McClean et al. 1998). In addition, the choice of scale of analysis influences the amount of habitat deemed available (Johnson 1980, McClean et al. 1998). In the coarsest scale of analysis, deer use of cover types within seasonal ranges during the winters of 1995 and 1996 was compared to that expected based on the composition of the entire seasonal range. This analysis was analogous to Johnson's (1980) second-order selection and reflects patterns of selection of home ranges from within the surrounding landscape. Our predictions concerning snow-depth were evaluated at this seasonal-range scale. Deer locations were paritioned by three snow depth levels, measured in open areas, Oupon which the study predictions were based $(<20,20-40$, $\$ 40 \mathrm{~cm}$ ), and analyzed separately. Data from 1997, which were insufficient for separate analysis but which included the OJdeepest snow depths encountered during the study, were dpooled with those of 1995 and 1996 to test these predictions. In the finest scale of analysis, deer use of cover types Iwithin home ranges during the winters of 1995 and 1996 was compared to expected use based on composition of the home ranges, pooled for each seasonal range. This analysis was analogous to Johnson's (1980) third-order selection.

Chi-square goodness-of-fit tests were used to analyze deer locations for evidence of cover type selection (Neu et al. 1974, Byers et al. 1984). Expected frequencies within individual categories were $>1$, and no more than $20 \%$ of expected frequencies were $<5$ (Zar 1984). Because of the low proportion of juveniles and male deer in the sample, data from all sexes and age-classes were pooled.

Each triangulated deer location had an associated error area, and prior to analyses of cover type selection, locations were screened by error ellipse size. The analyses address deer use of cover type patches, formed by aggregating adjacent stands with identical cover type designations. Average patch size was $11.0 \pm 0.62(\mathrm{SE})$ ha and $14.9 \pm 3.6(\mathrm{SE})$ ha at Snider Mountain and Mount Hebron, respectively. Although spatial data were not available to determine patch size on the remaining seasonal ranges, we assumed that mean sizes would be comparable. Data were screened to remove all deer locations with error ellipses $>10$ ha, an area slightly smaller than the smallest mean patch size. Most locations had errors well below mean cover patch size, since the mean error area in the screened data set for all deer was $1.2 \pm 0.04(\mathrm{SE}) \mathrm{ha}$, and $95 \%$ of all error areas were $<4.9$ ha $(n=1887)$.

\section{Results}

Sixty-three deer (14 male, 49 female) were captured between 7 March 1994 and 26 March 1995. Age-class composition at capture date was 49 adults, 8 yearlings, and 6 fawns. A total of 2588 locations of mostly adult female deer were collected during the study. These included 375 locations of 12 deer ( 7 ad. F, 3 juv. F, 1 ad. M, 1 juv. M) in winter 1995 (i.e., December 1994 - April 1995), 1457 locations of 31 deer (27 ad. F, 1 juv. F, 3 ad. M) in winter 1996, 216 locations of 24 deer (23 ad. F, 1 ad. M) in winter 1997, and 540 locations during non-winter periods in 1994-1997. There was no difference in number of locations in cover types between day and night intervals (ANOVA, $\mathrm{F}=0.169, P=0.69$ ), thus they were pooled for subsequent analyses. There was also no difference in number of locations in cover types between sexes (ANOVA, $\mathrm{F}=0.002, P=0.97$ ), thus data for male and female deer were pooled as well.

Three sub-populations of deer were evident, occupying three discrete wintering areas in the southern part of the study area: at Snider Mountain (approximately 5658 ha; $n=40$ deer), Mount Hebron (712 ha; $\mathrm{n}=6$ deer), and Whites Mountain ( 2307 ha; $n=13$ deer). These sub-populations also occupied distinct summer ranges directly north of their respective wintering areas. Four collared deer were not part of any identifiable sub-population and were excluded from our analyses.

\section{Cover Type Selection Within Seasonal Ranges Snider Mountain}

Deer on the Snider Mountain wintering area did not use cover types in proportion to availability based on seasonal range composition neither in 1995 nor $1996(P<0.001)$ (Table 1$)$. During the relatively severe winter of 1995 , deer preferred mixedwoods, and avoided several open-canopy cover types, as well as softwood stands. Habitat selection during the moderate winter of 1996 differed from that in 1995, with deer preferring both softwood and mixedwood stands. Open-canopy cover types were avoided in 1996. Deer were present on the Snider Mountain summer range during much of winter 1996, and did not use cover types on this range in proportion to availability $(P<0.001)$ (Table 1$)$. Mixedwood and regenerating stands were preferred, while plantations and agricultural areas were avoided.

\section{Mount Hebron and Whites Mountain}

Deer did not use cover types in proportion to availability based on seasonal range composition on the Mount Hebron wintering area $(P<0.001)$, but they did on Whites Mountain $(P>0.05)$. Deer on Mount Hebron preferred mixedwoods, and avoided agricultural areas, a pattern of use consistent with that at Snider Mountain.

\section{Cover Type Selection Within Home Ranges Snider Mountain}

Deer did not use cover types in proportion to availability based on pooled home range composition, in 1995 or $1996(\mathrm{P}<0.05)$ (Table 2). During winter 1995, collared deer avoided mixedwood saplings, while preferring the older mixedwood cover type. During winter 1996, mixedwood saplings were again avoided, while softwoods were preferred. On the Snider Mountain summer range during winter 1996, cover types 
Table 1. Chi-square analyses of winter cover-type selection by white-tailed deer with percent use (U) and availability (A) defined by seasonal rang composition, 1995-1996. Direction of signs indicate cover types that were avoided (-) or preferred (+) according to $95 \%$ Bonferroni confidence inter vals. Dashed lines indicate cover types not represented

\begin{tabular}{|c|c|c|c|c|c|c|c|c|c|c|}
\hline \multirow[b]{2}{*}{ Cover Type } & \multicolumn{2}{|c|}{ SMWA-1995' } & \multicolumn{2}{|c|}{ SMWA-1996 } & \multicolumn{2}{|c|}{ SMSR-1995 } & \multicolumn{2}{|c|}{ MHWA-1995 } & \multicolumn{2}{|c|}{ WMWA-1995 } \\
\hline & $\mathrm{A}$ & $\mathrm{U}$ & $\mathrm{A}$ & $\mathrm{U}$ & A & $\mathrm{U}$ & $\mathrm{A}$ & $\mathrm{U}$ & $\mathrm{A}$ & $\mathrm{U}$ \\
\hline Softwood & 15.0 & $7.1-$ & 15.0 & $23.5+$ & 18.0 & 15.0 & 13.8 & 24.0 & 7.9 & 3. \\
\hline Plantation & 3.0 & 2.8 & 3.0 & $0.3-$ & 6.2 & $1.7-$ & - & - & 3.8 & 3.1 \\
\hline $\begin{array}{l}\text { Regenerating } \\
\text { Clearcuts }\end{array}$ & 2.1 & 0.0 & 2.1 & 1.6 & 6.6 & $12.7+$ & - & - & 10.8 & 6.8 \\
\hline Mixedwood & 39.7 & $64.4+$ & 39.7 & $50.8+$ & 52.3 & $55.7+$ & 39.2 & $53.0+$ & 23.6 & 28.1 \\
\hline Hardwood & 7.4 & $2.8-$ & 7.4 & 7.4 & - & - & 14.0 & 9.0 & 40.7 & $47 .^{\circ}$ \\
\hline Saplings & 21.8 & $14.7-$ & 21.8 & $12.5-$ & 15.9 & 15.0 & 9.7 & 9.0 & 13.2 & 10.1 \\
\hline $\begin{array}{l}\text { Agricultural } \\
\text { Lands }\end{array}$ & 10.9 & 8.1 & 10.9 & $4.0-$ & 1.1 & $0.0-$ & 23.3 & $5.0-$ & - & - \\
\hline $\mathrm{N}$ & \multicolumn{2}{|c|}{211} & \multicolumn{2}{|c|}{703} & \multicolumn{2}{|c|}{300} & \multicolumn{2}{|c|}{100} & \multicolumn{2}{|c|}{132} \\
\hline$P$ & \multicolumn{2}{|c|}{$<0.001$} & \multicolumn{2}{|c|}{$<0.001$} & \multicolumn{2}{|c|}{$<0.001$} & \multicolumn{2}{|c|}{$<0.001$} & \multicolumn{2}{|c|}{0.138} \\
\hline
\end{tabular}

${ }^{1}$ SMWA (Snider Mountain Wintering Area); SMSR (Snider Mountain Summer Range); MHWA (Mount Hebron Wintering Area); and WMWA (Whites Mountain Wintering Area).

Table 2. Chi-square analyses of winter cover-type selection by white-tailed deer with percent use (U) and availability (A) defined by home range com position, 1995-1996. Direction of signs indicate cover types that were avoided (-) or preferred (+) according to $95 \%$ Bonferroni confidence intervals Dashed lines indicate cover types not represented

\begin{tabular}{|c|c|c|c|c|c|c|c|c|c|c|}
\hline \multirow[b]{2}{*}{ Cover Type } & \multicolumn{2}{|c|}{ SMWA-1995' } & \multicolumn{2}{|c|}{ SMWA-1996 } & \multicolumn{2}{|c|}{ SMSR-1995 } & \multicolumn{2}{|c|}{ MHWA-1995 } & \multicolumn{2}{|c|}{ WMWA-1995 } \\
\hline & $\mathrm{A}$ & $\mathrm{U}$ & $\mathrm{A}$ & $\mathrm{U}$ & $\mathrm{A}$ & $\mathrm{U}$ & $\mathrm{A}$ & $\mathrm{U}$ & $\mathrm{A}$ & $\mathrm{U}$ \\
\hline Softwood & 9.2 & 8.7 & 19.6 & $24.5+$ & 13.2 & 15.3 & 11.1 & $23.5+$ & 7.1 & 3.3 \\
\hline Plantation & - & - & - & - & 2.7 & 1.7 & - & - & 3.2 & 3.3 \\
\hline $\begin{array}{l}\text { Regenerating } \\
\text { Clearcuts }\end{array}$ & - & - & 1.4 & 1.6 & 12.9 & 13.2 & - & - & 9.0 & 5.8 \\
\hline Mixedwood & 58.2 & $68.6+$ & 50.7 & 50.3 & 58.0 & 54.5 & 54.0 & 53.1 & 26.8 & $29 . \mathrm{C}$ \\
\hline Hardwood & 1.8 & 1.2 & 7.7 & 7.6 & - & - & 16.2 & $9.2-$ & 45.8 & 49.6 \\
\hline Saplings & 24.1 & $13.9-$ & 15.8 & $12.2-$ & 13.2 & 15.3 & 6.7 & 9.2 & 8.2 & 9.1 \\
\hline $\begin{array}{l}\text { Agricultural } \\
\text { Lands } \\
\end{array}$ & 6.7 & 7.6 & 4.9 & 3.9 & - & - & 12.1 & $5.1-$ & - & - \\
\hline $\mathrm{N}$ & \multicolumn{2}{|c|}{172} & \multicolumn{2}{|c|}{674} & \multicolumn{2}{|c|}{288} & \multicolumn{2}{|c|}{98} & \multicolumn{2}{|c|}{121} \\
\hline$P$ & \multicolumn{2}{|c|}{0.025} & \multicolumn{2}{|c|}{0.007} & \multicolumn{2}{|c|}{0.482} & \multicolumn{2}{|c|}{$<0.001$} & \multicolumn{2}{|c|}{0.475} \\
\hline
\end{tabular}

${ }^{1}$ SMWA (Snider Mountain Wintering Area); SMSR (Snider Mountain Summer Range); MHWA (Mount Hebron Wintering Area); and WMWA (Whites Mountain Wintering Area).

were used in proportion to their availability $(P>0.05)$ (Table 2).

\section{Mount Hebron and Whites Mountain}

Deer did not use cover types in proportion to their availability based on home range composition on the Mount Hebron wintering area in $1996(P<0.001)$ (Table 2). Softwood stands were preferred, and agricultural land was avoided. Cover types were used in proportion to availability on the Whites Mountain wintering area in $1996(P>0.05)$ (Table 2).

\section{Snow Depth and Cover Type Selection}

Sample size was adequate to partition observations by snow depth classes only for Snider Mountain wintering area and for the Snider Mountain summer range. Data were insufficient to test for cover type selection at the deepest snow level on the Snider Mountain summer range $(\mathrm{n}=3)$.

\section{Snider Mountain Wintering Area}

Cover types were not used in proportion to availability at all snow depths $(P<0.001)$ (Table 3$)$. Five open-canopy cover 
Table 3. Results of chi-square analysis of winter cover-type selection by white-tailed deer on Snider Mountain Wintering Area, New Brunswick, 1995-1997. Data are stratified by snow-depth class. Percent use (U) and availability (A) of cover types is defined by seasonal range composition. Direction of signs indicate cover types that were avoided $(-)$ or preferred (+) according to $95 \%$ Bonferroni confidence intervals. Dashed lines indicate cover types not represented

\begin{tabular}{|c|c|c|c|c|c|c|}
\hline \multirow[b]{2}{*}{ Cover Type } & \multicolumn{2}{|c|}{ Snow $<20 \mathrm{~cm}$} & \multicolumn{2}{|c|}{ Snow $20-40 \mathrm{~cm}$} & \multicolumn{2}{|c|}{ Snow $>40 \mathrm{~cm}$} \\
\hline & A & $\mathrm{U}$ & A & $\mathrm{U}$ & A & $\mathrm{U}$ \\
\hline Softwood & 15.0 & $23.3+$ & 15.0 & $23.4+$ & 15.0 & $9.0-$ \\
\hline Plantation & 3.0 & $0.2-$ & 3.0 & 0.9 & 3.0 & 2.7 \\
\hline $\begin{array}{l}\text { Regenerating } \\
\text { Clearcuts }\end{array}$ & 2.1 & 2.1 & 2.1 & 1.1 & 2.1 & 1.1 \\
\hline Mixedwood & 39.7 & $50.5+$ & 39.7 & $49.7+$ & 39.7 & $67.2+$ \\
\hline Hardwood & 7.4 & 7.9 & 7.4 & 6.3 & 7.4 & $3.2-$ \\
\hline Saplings & 21.8 & $11.5-$ & 21.8 & $14.0-$ & 21.8 & $12.7-$ \\
\hline $\begin{array}{l}\text { Agricultural } \\
\text { Lands }\end{array}$ & 10.9 & $4.3-$ & 10.9 & $4.6-$ & 10.9 & $4.2-$ \\
\hline $\mathrm{N}$ & \multicolumn{2}{|c|}{514} & \multicolumn{2}{|c|}{350} & \multicolumn{2}{|c|}{189} \\
\hline$P$ & \multicolumn{2}{|c|}{$<0.001$} & \multicolumn{2}{|c|}{$<0.001$} & \multicolumn{2}{|c|}{$<0.001$} \\
\hline
\end{tabular}

types were avoided at one or more snow-depth levels, with agricultural lands and mixedwood saplings being avoided at all snow depths. Two cover types were used more often than expected: mixedwood was preferred at all snow depths while softכwoods were preferred at the shallower (i.e., $<20,20-40 \mathrm{~cm}$ ) Fdepths.

\section{Snider Mountain Summer Range}

Cover types were not used in proportion to their availability on the summer range at both snow depths (Table 4). Regenerating stands were preferred by deer at snow depths $<20 \mathrm{~cm}$, while agricultural lands and plantations were avoided at both depths.

\section{Discussion}

Stronger patterns of selection occurred for the coarser scale of analyses (within seasonal ranges) as compared to the finer within-home-range scale. Significance levels were higher at the coarser scale, and a greater number of cover types were preferred or avoided (Tables 1 and 2). This may have occurred because as the area used to determine availability (i.e., extent) decreases, availability approaches use (McClean et al. 1998).

The general pattern of cover type selection exhibited by deer on wintering areas was an avoidance of open and young cover types, and a preference for mixedwood types regardless of snow depth. Cover-type selection patterns by deer wintering on the Snider Mountain summer range during low snow periods differed from that on the wintering areas somewhat in that open, regenerating stands were preferred, while no preference was shown for mixedwoods.

Preference for mixedwood stands by white-tailed deer under moderate snow depths has been documented previously (Telfer 1970, Drolet 1976, Euler and Thurston 1980, Gates and Harman 1980, and Mooty et al. 1987). Mixedwood stands do not provide the uniform amelioration of snow depths possi-
Table 4. Chi-square analyses of winter cover-type selection by white-tailed deer on the Snider Mountain summer range, New Brunswick, 1996. Data are stratified by snow-depth class. Percent use (U) and availability (A) of cover types is defined by seasonal range composition. Direction of signs indicate cover types that were avoided $(-)$ or preferred $(+)$ according to 95\% Bonferroni confidence intervals. Dashed lines indicate cover types not represented

\begin{tabular}{|c|c|c|c|c|}
\hline \multirow[b]{2}{*}{ Cover Type } & \multicolumn{2}{|c|}{ Snow $<20 \mathrm{~cm}$} & \multicolumn{2}{|c|}{ Snow $20-40 \mathrm{~cm}$} \\
\hline & A & $\mathrm{U}$ & $\mathrm{A}$ & $\mathrm{U}$ \\
\hline Softwood & 18.0 & 13.4 & 18.0 & 17.2 \\
\hline Plantation & 6.2 & $2.1-$ & 6.2 & $0.7-$ \\
\hline $\begin{array}{l}\text { Regenerating } \\
\text { Clearcuts }\end{array}$ & 6.6 & $13.4+$ & 6.6 & 10.7 \\
\hline Mixedwood & 52.3 & 56.7 & 52.3 & 53.6 \\
\hline Hardwood & - & - & - & - \\
\hline Saplings & 15.9 & 14.4 & 15.9 & 17.9 \\
\hline $\begin{array}{l}\text { Agricultural } \\
\text { Lands }\end{array}$ & 1.1 & 0.0 & 1.1 & 0.0 \\
\hline$N$ & \multicolumn{2}{|c|}{187} & \multicolumn{2}{|c|}{140} \\
\hline$P$ & \multicolumn{2}{|c|}{$<0.001$} & \multicolumn{2}{|c|}{0.029} \\
\hline
\end{tabular}

ble under a pure conifer canopy, but they do provide a moderate to high degree of conifer cover relative to open areas and hardwood stands. Many studies of browse abundance indicate that browse in mixedwood stands typically is moderately high, surpassed only by that in deciduous and open or regenerating stands, while browse abundance in softwood stands is comparatively low (Webb 1948, Wetzel et al. 1975, Potvin and Huot 1983, Monthey 1984, Mooty et al. 1987, Schmitz 1991). Preliminary surveys at Canaan River supported this pattern; browse was abundant in mixedwoods, exceeded only by hardwoods and regenerating cuts, and was low in pure softwood stands (unpublished data). Thus, mixedwoods produce sub-maximal levels of conifer cover and browse supply, but are the only vegetation types providing both simultaneously. This combination of food and cover characteristic of mixedwoods may be sufficient for selection by deer under moderate winter climate conditions.

Our first prediction, that cover availability is the primary factor determining selection by deer at snow depths $>40 \mathrm{~cm}$; thus, softwood stands are preferred, was not supported. Softwood cover types provide the highest degree of canopy cover available, and thus, are often preferred by deer in northern deer yards. Nonetheless, softwoods were not preferred by deer in deep snow in our study. The second prediction, that both food and cover influence habitat use at snow depths $20-40 \mathrm{~cm}$; thus, use of softwood stands diminishes in favour of open-canopy stands with high browse production, was not rejected. Deer preferred both mixedwoods and softwoods at snow depths of $20-40 \mathrm{~cm}$, on the wintering area, while no preference was shown on the summer range (Tables 3 and 4). Our third prediction, that food is the primary factor determining habitat use at snow depths $<20 \mathrm{~cm}$; thus, softwood stands are avoided and open-canopy stands are preferred, was not supported. Although deer were unrestricted in movement and in access to browserich hardwoods and clearcuts at snow depths $<20 \mathrm{~cm}$, these 
cover types were generally avoided. An exception was on the Snider Mountain summer range, where regenerating stands were preferred. This probably occurred because deer occupied summer range during winter only when snow depths were exceptionally low.

The dominant pattern evident during this study was that moderate levels of coniferous cover in mixedwood stands were sufficient to provide cover for deer over the range of snow conditions encountered. While some jurisdictions in northeastern North America have developed guidelines for the provision of winter shelter in deer wintering areas which include management for mixedwood cover types (e.g., Québec: Anon 1998, New Brunswick - Anon 1999), others place priority on management of softwood cover (e.g., Nova Scotia-Anon 1989, Vermont - Reay et al. 1990, Ontario - Voigt 1991). While we recognize the importance of softwood wintering areas for deer populations during severe winters, we caution managers throughout northeastern North America that mixedwood cover types may also be important for deer survival during winter in areas where winters are of moderate severity.

\section{Acknowledgements}

Funding for this study was provided by the Fundy Model Forest, the New Brunswick Department of Natural Resources and Energy, J. D. Irving Ltd., the New Brunswick Cooperative Agreement on Forest Development, and the New Brunswick Cooperative Fish and Wildlife Research Unit. We gratefully acknowledge A. Boer, J. Gilbert, S. Lusk, T. Pettigrew, G. Redmond, M. Sullivan, and L. Vietinghoff, for their logistical support. Field work assistance was provided by S. Farrell, E. Sullivan, G. Cormier, and G. Leblanc.

\section{References}

Anon. 1989. Forest/wildlife guidelines and standards for Nova Scotia. Nova Scotia Department of Lands and Forests. 19 p.

Anon. 1991. Forest land habitat management program progress report. New Brunswick Department of Natural Resources and Energy. 57 p.

Anon. 1998. Guide d'aménagemant des ravages de cerfs de Virginie. Environnement et Faune Québec. 78 p.

Anon. 1999. A vision for New Brunswick forests. New Brunswick Department of Natural Resources and Energy. 44 p.

Ballard, W.B., H.A. Whitlaw, D.L. Sabine, R.A. Jenkins, S.J. Young and G.J. Forbes. 1998. White-tailed deer, Odocoileus virginianus, capture techniques in yarding and non-yarding populations in New Brunswick. Canadian Field-Naturalist 112: 254-261.

Beier, P. and D.R. McCullough. 1990. Factors influencing whitetailed deer activity patterns and habitat use. Wildlife Monographs 109: $1-51$.

Byers, C.R., R.K. Steinhorst and P.R. Krausman. 1984. Clarification of a technique for analysis of utilization-availability data. Journal of Wildlife Management 48: 1050-053.

Drolet, C.A. 1976. Distribution and movements of white-tailed deer in southern New Brunswick in relation to environmental factors. Canadian Field-Naturalist 90: 123-136.

Euler, D. and L. Thurston. 1980. Characteristics of hemlock stands related to deer use in east-central Ontario. Journal of Applied Ecology 17: 1-6.

Gates, J.E. and D.M. Harman. 1980. White-tailed deer wintering in a hemlock-northern hardwood forest. Canadian Field-Naturalist 94: 259-268.

Hamerstrom, F.N. and J. Blake. 1939. Winter movements and winter foods of white-tailed deer in central Wisconsin. Journal of Mammalogy 20: 206-215.
Huot, J. 1974. Winter habitat of white-tailed deer at Thirty-One Mil Lake, Quebec. Canadian Field-Naturalist 88: 293-301.

Johnson, D.H. 1980. The comparison of usage and availability measurements for evaluating resource preference. Ecology 61 65-71.

Kelsall, J.P. 1969. Structural adaptations of deer and moose for snow Journal of Mammalogy 50: 302-310.

Kelsall, J.P. and W. Prescott. 1971. Moose and deer behaviour ir snow. Canadian Wildlife Service Report Series 15. 27 p.

Kucera, E. 1976. Effects of winter conditions on the white-tailed dee of Delta Marsh, Manitoba. Canadian Journal of Zoology 54 1307-1313.

McClean, S.A., M.A. Rumble, R.M. King and W.L. Baker. 1998 Evaluation of resource selection methods with different definition: of availability. Journal of Wildlife Management 62: 793-801.

Messier, F. and C. Barrette. 1985. The efficiency of yarding behavior by white-tailed deer as an anti-predator strategy. Canadi. an Journal of Zoology 63: 785-789.

Moen, A.N. 1968. Surface temperatures and radiant heat loss from white-tailed deer. Journal of Wildlife Management 32: 338-344.

Moen, A.N. 1976. Energy conservation by white-tailed deer in the winter. Ecology 57: 192-198.

Monthey, R.W. 1984. Effects of timber harvesting on ungulates ir Northern Maine. Journal of Wildlife Management 48: 279-285.

Mooty, J.J., P.D. Karns and T.K. Fuller. 1987. Habitat use and seasonal range of white-tailed deer in northcentral Minnesota. Journa of Wildlife Management 51: 644-648.

Nams, V.O. 1990. Locate II user's guide. Pacer, Truro, Nova Scotia, Canada.

Nelson, M.E. and L.D. Mech. 1981. Deer social organization anc wolf predation in northeastern Minnesota. Wildlife Monographs 77: 1-53.

Neu, C.W., C.R. Byers and J.M. Peek. 1974. A technique for analysis of utilization-availability data. Journal of Wildlife Managemen 38: 541-545.

Orians, G.H. and J.F. Wittenberger. 1991. Spatial and temporal scales in habitat selection. The American Naturalist 137: s29-s49. Ozoga, J.J. 1968. Variations in the micro-climate in a conife swamp deer yard in northern Michigan. Journal of Wildlife Management 32: $574-585$.

Ozoga, J.J. and L.W. Gysel. 1972. Response of white-tailed deeI to winter weather. Journal of Wildlife Management 36: 892-896.

Parker, K.L., C.T. Robbins and T.A. Hanley. 1984. Energy expenditures for locomotion by mule deer and elk. Journal of Wildlife Management 48: 474-488.

Pauley, G.R., J.M. Peek and P. Zager. 1993. Predicting white-tailed deer habitat use in northern Idaho. Journal of Wildlife Management 57: 904-913.

Phillips, D. 1990. The climates of Canada. Minister of Supply and Services Canada. 176 p.

Potvin, F. and J. Huot. 1983. Estimating carrying capacity of a whitetailed deer wintering area in Quebéc. Journal of Wildlife Management 47: 463-475.

Reay, R.S., D.W. Blodgett, B.S. Burns, S.J. Weber and T. Frey. 1990. Management guide for deer wintering areas in Vermont. Vermont Department of Forests, Parks and Recreation, and Vermont Department of Fish and Wildlife. 35 p.

Sabine, D.L. 1999. Migration behaviour and winter habitat use of white-tailed deer under moderate winter climate conditions. M. Sc. Thesis, University of New Brunswick, Fredericton, NB. 101 p.

Schmitz, O.J. 1991. Thermal constraints and optimization of winter feeding and habitat choice in white-tailed deer. Holarctic Ecology 14: 104-111.

Telfer, E.S. 1970. Winter habitat selection by moose and white-tailed deer. Journal of Wildlife Management 34: 554-559.

Verme, L.J. 1973. Movements of white-tailed deer in upper Michigan. Journal of Wildlife Management 37: 545-552. 
Voigt, D.R. 1991. Timber management guidelines for the provision of white-tailed deer habitat. Ontario Ministry of Natural Resources. $33 \mathrm{p}$.

Webb, W.L. 1948. Environmental analysis of a winter deer range. Transactions of the North American Wildlife Conference 13: 442-450.

Wetzel, J.F., J.R. Wambaugh and J.M. Peek. 1975. Appraisal of white-tailed deer winter habitats in northeastern Minnesota. Journal of Wildlife Management 39: 59-66.
White, G.C. and R.A. Garrott. 1990. Analysis of radio-tracking data. Academic Press, Inc., London. 383 p.

Whitlaw, H. A., W.B. Ballard, D. L. Sabine, S.J. Young, R.A. Jenkins and G.J. Forbes. 1998. Survival and cause-specific mortality rates of adult white-tailed deer in New Brunswick. Journal of Wildlife Management 62: 1335-1341.

Zar, J.H. 1984. Biostatistical analysis. Prentice-Hall, Inc., Englewood Cliffs, N.J. 718 p. 